BOTANICA

ISSN 2538-8657

2020, 26(1): $15-27$

\title{
GENERA EUASTRUM AND MICRASTERIAS (CHAROPHYTA, DESMIDIALES) FROM FENS IN THE SOUTHERN PART OF MIDDLE URALS, RUSSIA
}

\author{
Andrei S. Shakhmatov \\ Ural Federal University, Institute of Natural Sciences and Mathematics, Kuybysheva Str. 48, \\ 620000 Ekaterinburg, Russia \\ Corresponding author. E-mail: shahmatov1992@mail.ru
}

\begin{abstract}
Shakhmatov A.S., 2020: Genera Euastrum and Micrasterias (Charophyta, Desmidiales) from fens in the southern part of Middle Urals, Russia. - Botanica, 26(1): 15-27.

The floristic survey of the desmids in lakes of the southern part of Middle Urals revealed nine species representing the genus Euastrum and eight taxa belonging to the genus Micrasterias. Among them, four taxa (Euastrum germanicum, E. verrucosum var. alatum, Micrasterias fimbriata, M. mahabuleshwarensis var. wallichii) were new records to the Ural Region, whereas the other four taxa (Euastrum verrucosum, Micrasterias americana, M. furcata and M. truncata) were found for the first time in Middle Urals. Canonical correspondence analysis, which was performed to assess habitat preferences of the studied algae, showed that most species were more abundant in slightly acidic water and occurred predominantly in benthic habitats.
\end{abstract}

Keywords: Chelyabinsk Region, Conjugatophyceae, Desmidiaceae, distribution, new records, Sverdlovsk Region.

\section{INTRODUCTION}

The southern part of Middle Urals on its eastern macroslope, in contrast to other parts of its territory, has a number of lakes. Some of them such as Lakes Sinara and Itkul have large water surface areas (up to $30.1 \mathrm{~km}^{2}$ ), great depths (up to $20 \mathrm{~m}$ ) and, as a result, large reserves of fresh water, which is used by neighbouring villages, cities and industrial enterprises. In addition, these lakes usually have sandy or pebbly shores, which make them attractive for recreational purposes. For the above-mentioned reasons, these reservoirs have been actively studied since the beginning of the $20^{\text {th }}$ century, including researches into the biodiversity of algae (YARUSHINA \& EREMKINA, 2000; YARUSHINA et al., 2004 and references therein; EREMKINA, 2009).

Another, much larger part of water bodies of this territory is made up of shallower (less than 10 metres deep) and much smaller lakes (about $1 \mathrm{~km}$ across) with wetlands along the shores. These reservoirs have not been studied by algologists in detail de- spite the apparently favourable conditions for algae of various groups, including the order Desmidiales. Representatives of this order are known as sensitive indicators of a state of aquatic and wetland ecosystems (BrooK, 1981; CoEsel, 1975), which makes the studies on their biodiversity and ecology extremely important, especially in the regions with developed industry such as the territory under consideration.

The current work is devoted to study the biodiversity and ecology of the two Desmidiacean genera, Micrasterias and Euastrum, in the south-eastern part of Middle Urals. The results of this work will complement the knowledge about the biological diversity of these genera both in Middle Urals and in the Ural Region as a whole.

\section{STUDY AREA}

According to the administrative subdivision, the territory under consideration is situated in the Russian Federation, at the border of Sverdlovsk and Chelyab- 
insk Regions. The studied area belongs to the Tobol River basin (ANDREEVA, 1973), and is situated near the southern border of Middle Urals, on its eastern slope (Fig. 1, A). Geologically, it belongs to the Middle trans-Uralean province (ChiBiLyov \& ChIBILYov, 2012). The region is characterized by a moderately continental climate with long cold winters, short warm summers and short springs and autumns. The average monthly air temperature varies from -15 to $-16^{\circ} \mathrm{C}$ in the coldest month (January) and from 16 to $+17^{\circ} \mathrm{C}$ in the warmest month (July). The annual precipitation is about $500-800 \mathrm{~mm}$. The vegetation of the region is represented mainly by the middle taiga pine (Pinus sylvestris L.) forests, with ground cover depending on water availability dominated by grasses or Sphagnum mosses (predominantly Sphagnum girgensohnii Rus- sow and Sphagnum squarrosum Crome). Due to the long-term impact of logging and fires, the vegetation dominated by pine has been replaced by birch (Betula pendula Roth, Betula pubescens Ehrh.) and aspen (Populus tremula L.) in large areas. Some territories are covered by post-forest meadows (KuLIKOv, 2010).

\section{MATERIALS AND METHODS}

The present research was carried out in 11 tectonic lakes in May-August 2013-2016 (ANDREEVA, 1973), wherein the largest three (Schelkunskoye, Okunkul, Karaguz) have pebbly banks and eutrophic water, the next five (Boevskoye, Tenyak, Cherkaskul, Maloye Yamskoye, Bolshoye Yamskoye) are mesotrophic open-water transition fens with floating peat mats
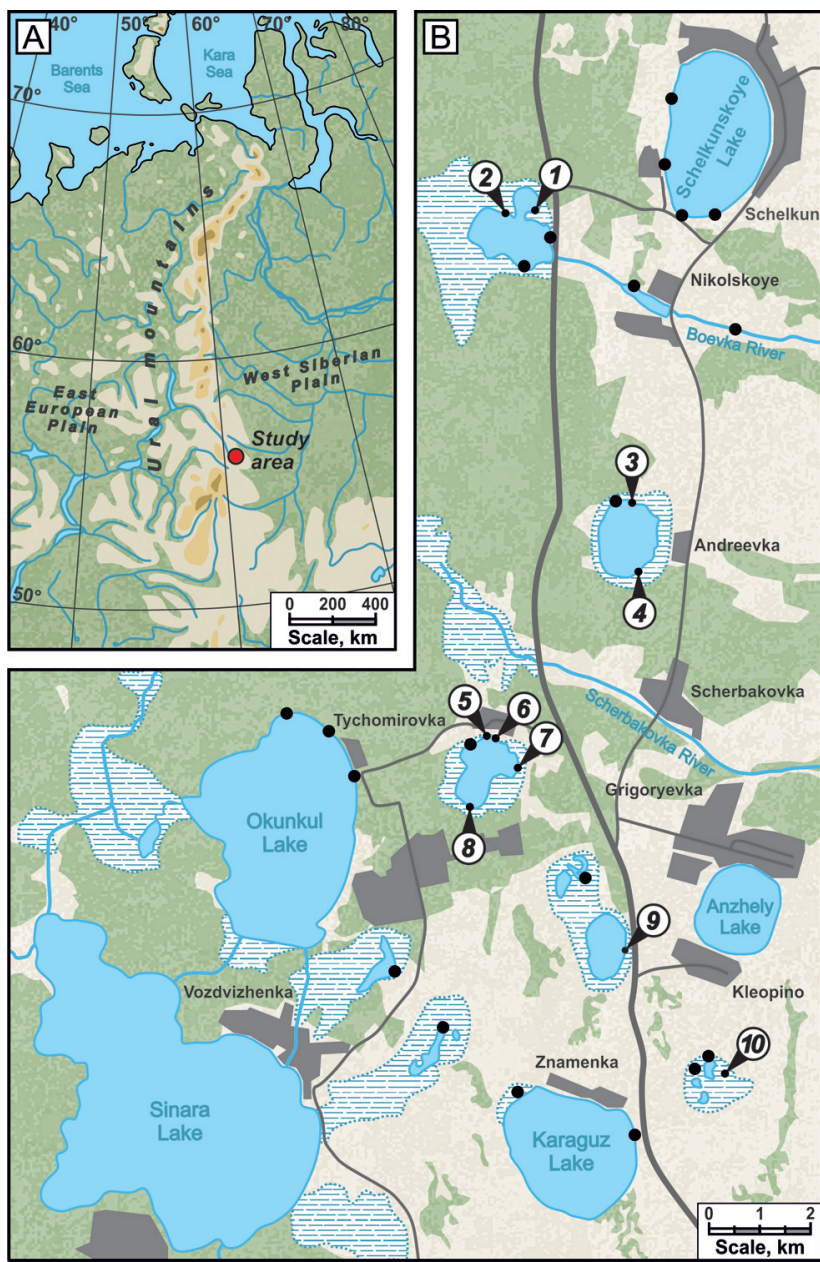

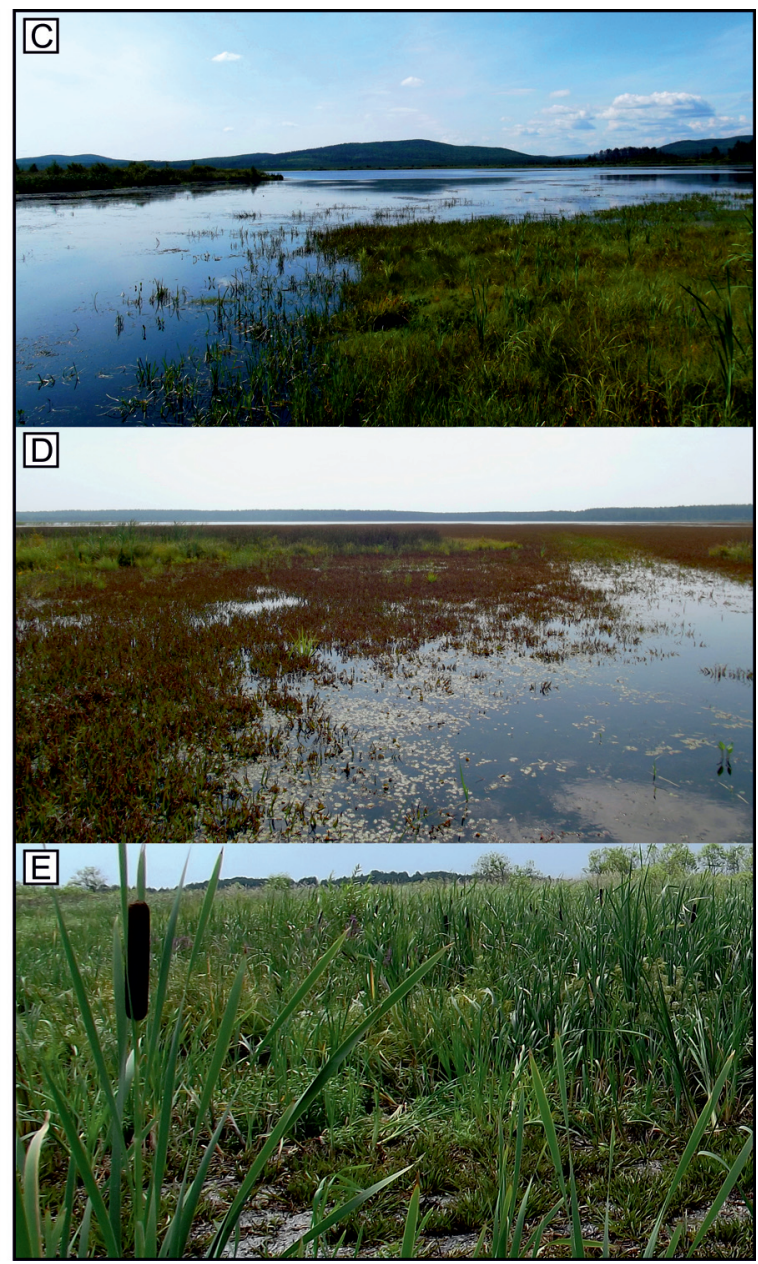

Fig. 1. Study area with sampling sites in the selected lakes $(A, B)$ and photographs of typical biotopes $(C-$ open-water transition fen in Lake Boevskoye, D - floating peat mat in Lake Tenyak, E - quaking fen in Lake Travyanoye). The numbers on the map indicate sampling sites on the lakes: 1-2 - Boevskoye, 3-4 - Tenyak, 5-8-Cherkaskul, 9 - Bolshoye Yamskoye, 10 - Travyanoye 
(Fig. $1 \mathrm{C}, \mathrm{D})$, and the last three (Chigany, Bagaryay, Travyanoye) have almost turned into meso-eutrophic quaking fens (Fig. 1 E) (YarushinA et al., 2004). All mentioned lakes are located at the elevation of 251257.8 metres above the sea level and have $\mathrm{pH}$-value ranging from weakly acidic to slightly alkaline.

The sampling on each lake was made at several sites (Table 1 describes only those, where Euastrum and Micrasterias species were found). Plankton samples were collected using the Apstein plankton net with a mesh about $20 \mu \mathrm{m}$ in size; benthos samples were taken with a small amount of substrate (silt, peat, and sapropel) into $50 \mathrm{ml}$ plastic tubes. In parallel with the sampling, the temperature and $\mathrm{pH}$ of the water were measured using a portable $\mathrm{pH}$-meter Milwaukee pH55 Martini.

The study of live algal samples was carried out using a light microscope Levenhuk 320, Micmed-2 and a digital camera Levenhuk C310 NG. Cell measurements were made using ToupView v.3.7 software. The abundance estimation was made according to a 6-point scale (KoRde, 1956; Barinova \& Medvedeva, 1996), where 1 - "single" with 1-5 cells per slide, 2 - "rare" with 10-15 cells, 3 - "common" with 25-30 cells, 4 - "frequent" with one cell over a slide transect, 5 - "very frequent" several cells over a slide transect, 6 - "abundant" with one or more cells in each field of view. Species identification was performed using flora books (KosinsKaya, 1960; LENzenweger, 1996; Coesel \& Meesters, 2007).

In the annotated list, the names of taxa were given in accordance with Algaebase (GUIRY \& GUIRY, 2019). In species description, the following abbreviations were used: Dim. - cell dimensions; Descr. short description of the cell morphology; Loc. - location, where the species was detected, given with

Table 1. Description of the sampling sites in which the Euastrum and Micrasterias species were found. Row numbers correspond to the site numbers in Fig. $1 \mathrm{~B}$

\begin{tabular}{|c|c|c|c|c|}
\hline No & Coordinates & $\mathrm{pH}$ & $\mathrm{t}, \mathrm{C}^{\circ}$ & Description \\
\hline 1 & $\begin{array}{l}\text { N } 56^{\circ} 16^{\prime} 53.4^{\prime \prime} \\
\text { E } 60^{\circ} 52^{\prime} 02.4^{\prime \prime}\end{array}$ & 6.0 & 22.0 & $\begin{array}{l}\text { Lake Boevskoye. The plankton and benthos samples were taken in wetlands near } \\
\text { the lake shore covered with Typha latifolia L., Phragmites australis (Cav.) Trin. } \\
\text { ex Steud., Calla palustris L. Stratiotes aloides L. and Utricularia intermedia } \\
\text { Hayne were found in the water. }\end{array}$ \\
\hline 2 & $\begin{array}{l}\text { N } 56^{\circ} 16^{\prime} 41.3^{\prime \prime} \\
\text { E } 60^{\circ} 51^{\prime} 35.8^{\prime \prime}\end{array}$ & 6.1 & 22.0 & Lake Boevskoye. Environmental conditions are similar to sampling site 1. \\
\hline 3 & $\begin{array}{l}\text { N } 56^{\circ} 13 ' 28.5^{\prime \prime} \\
\text { E } 60^{\circ} 53^{\prime} 55.9^{\prime \prime}\end{array}$ & 6.0 & 19.0 & $\begin{array}{l}\text { Lake Tenyak. The plankton samples were taken in wetlands near the lake shore } \\
\text { covered with Phragmites australis Typha latifolia, Alisma plantago-aquatica L., } \\
\text { Calla palustris, Comarum palustre L., Equisetum fluviatile L. Stratiotes aloides, } \\
\text { Utricularia intermedia Hayne and Hydrocharis morsus-ranae L. as well as } \\
\text { thickets of Chara globularis Thuiller and macroscopic Nostoc sp. colonies were } \\
\text { found in water. }\end{array}$ \\
\hline 4 & $\begin{array}{l}\text { N } 56^{\circ} 12^{\prime} 39.3^{\prime \prime} \\
\text { E } 60^{\circ} 53^{\prime} 54.4^{\prime \prime}\end{array}$ & 6.3 & 28.0 & $\begin{array}{l}\text { Lake Tenyak. The plankton and benthos samples were taken in the hollows of } \\
\text { lake peat shore covered with Typha latifolia and Phragmites australis. }\end{array}$ \\
\hline 5 & $\begin{array}{l}\text { N } 56^{\circ} 10^{\prime} 52.6^{\prime \prime} \\
\text { E } 60^{\circ} 50^{\prime} 58.1^{\prime \prime}\end{array}$ & 7.0 & 20.0 & $\begin{array}{l}\text { Lake Cherkaskul. The plankton samples were taken in wetlands near the lake } \\
\text { shore covered with Typha latifolia, Phragmites australis, Alisma plantago- } \\
\text { aquatica, Calla palustris, Comarum palustre, Equisetum fluviatile. Stratiotes } \\
\text { aloides, Utricularia intermedia were found in the water. }\end{array}$ \\
\hline 6 & $\begin{array}{l}\text { N } 56^{\circ} 10^{\prime} 53.2^{\prime \prime} \\
\text { E } 60^{\circ} 50^{\prime} 58.5^{\prime \prime}\end{array}$ & 8.0 & 27.1 & Lake Cherkaskul. Environmental conditions are similar to sampling site 5. \\
\hline 7 & $\begin{array}{l}\text { N } 56^{\circ} 10^{\prime} 37.9^{\prime \prime} \\
\text { E } 60^{\circ} 51^{\prime} 58.1^{\prime \prime}\end{array}$ & 7.0 & 23.0 & Lake Cherkaskul. Environmental conditions are similar to sampling site 5. \\
\hline 8 & $\begin{array}{l}\text { N } 56^{\circ} 10^{\prime} 05.3^{\prime \prime} \\
\text { E } 60^{\circ} 50^{\prime} 41.7^{\prime \prime}\end{array}$ & 6.9 & 21.0 & $\begin{array}{l}\text { Lake Cherkaskul. The plankton and benthos samples were taken in the hollows of } \\
\text { lake peat shore covered with Typha latifolia and Phragmites australis. }\end{array}$ \\
\hline 9 & $\begin{array}{l}\text { N } 56^{\circ} 08^{\prime} 40.1^{\prime \prime} \\
\text { E } 60^{\circ} 53^{\prime} 51.4^{\prime \prime}\end{array}$ & 7.0 & 26.0 & $\begin{array}{l}\text { Lake Bolshoye Yamskoye. The plankton samples were taken in wetlands near the } \\
\text { lake shore covered with Typha latifolia, Phragmites australis. Stratiotes aloides, } \\
\text { and Utricularia intermedia were found in water. }\end{array}$ \\
\hline 10 & $\begin{array}{l}\text { N } 56^{\circ} 07^{\prime} 15.3^{\prime \prime} \\
\text { E } 60^{\circ} 55^{\prime} 24.4^{\prime \prime}\end{array}$ & 7.2 & 23.2 & $\begin{array}{l}\text { Lake Travyanoye. The plankton samples were taken in fen hollows near lake } \\
\text { shore covered with dense thickets of Typha latifolia, Phragmites australis, } \\
\text { Comarum palustre L. and Calla palustris. }\end{array}$ \\
\hline
\end{tabular}


the number of sampling site according to Table 1 and abundance of taxa in the sample (in brackets); Hab. - habitats, where the species usually occur (given according to the above-mentioned flora books); Distr. - distribution in the Ural Mountains and in the neighbouring regions; G. distr. - global distribution of species in the world (given according to the Algaebase and the above-mentioned flora books).

The analysis of species composition similarity between the flora of the investigated lakes and the floras of different parts of the Ural Mountains was made using PAST 4.0 (HAMmER et al., 2001). The assessment of influence of the environmental conditions ( $\mathrm{pH}$, temperature) and habitat preferences was performed using Canoco 5.0 for Windows (TER BraAK \& Šmilauer, 2012).

\section{LIST OF SPECIES}

Here we provide an illustrated annotated list of the Micrasterias and Euastrum species found in the studied lakes.

\section{Genus Euastrum Ehrenberg ex Ralfs 1848}

Euastrum bidentatum Nägeli 1849 (Fig. 2, 1). Dim.: $52.4 \times 34.7 \mu \mathrm{m}$, polar lobe $20.5 \mu \mathrm{m}$ wide, isthmus $11.6 \mu \mathrm{m}$ wide. Descr.: cell elliptical in outline with deep closed sinus. Semi-cells with inflation in the mid-region, furnished with large granules. Basal lobes large, slightly concave on the top. Lateral lobes smaller, broadly rounded. Polar lobe convex with deep, narrow median incision and a spine on each angle. Cell wall granulated. Loc.: Lake Boevskoye No 1(1). Hab.: peat bogs, oligo-mesotrophic fens and rivers. Common at $\mathrm{pH}$ 5.5-7. Distr.: recorded in the Polar (VoRONIKHIN, 1930; PAtova \& Demina, 2007; BrišKaitĖ et al., 2016), Subpolar (Sterlyagova, 2008) and Middle (TAuson, 1947; Shakmmatov, 2014) Urals. Widespread in the most part of the East European Plain (KosinsKayA, 1960; LuKNITSKAYA, 2006; ANISSIMOVA, 2017), known from the Middle Cis-Urals (TAuson, 1947) and West Siberia (Kosinskaya, 1960; AleKsyuk et al., 1989; SAFonova \& Shaulo, 2007; Shakhmatov \& PaVlovskiy, 2019). G. distr.: widespread in both Northern and Southern Hemispheres.

Euastrum $c f$. denticulatum F.Gay 1884 (Fig. 2, 2) - Dim.: 25.8-37.1 × 21.1-29.8 $\mu \mathrm{m}$, polar lobe $14.8-17.3 \mu \mathrm{m}$ wide, isthmus $6.6-9.2 \mu \mathrm{m}$ wide.
Descr.: cell hexagonal in outline with deep closed sinus. Semi-cells with median inflation, furnished with large granules. Basal lobes large, slightly concaved on the top. Lateral lobes smaller, broadly rounded. Polar lobe truncated, with a v-shaped median incision and short spines on each angle. Cell wall has denticulations on the lobe margins. Loc.: Lake Boevskoye No 1(3); Lake Tenyak No 3(3). Hab.: peat bogs with Sphagnum, oligo-mesotrophic lakes and fens. Common at $\mathrm{pH}$ 4-7.2. Distr.: recorded in the Polar (BrišKaité et al., 2016), Subpolar (Sterlyagova, 2008) and Middle (Shakhmatov, 2014; as E. pulchellum in Shaкhmatov et al., 2018) Urals. Widespread in the most part of the East European Plain (Kosinskaya, 1960; LuKNitskaya, 2006; AnISSIMOVA, 2017), known from West Siberia (KosinSKAYA, 1960; NAUMENKO, 1992). G. distr.: widespread in both Northern and Southern Hemispheres.

Euastrum dubium Nägeli 1849 (Fig. 2, 3) - Dim.: $29.3 \times 21.5 \mu \mathrm{m}$, polar lobe $11.6 \mu \mathrm{m}$ wide, isthmus 5.9 $\mu \mathrm{m}$ wide. Descr.: cell hexagonal in outline with deep closed sinus. Semi-cells with small inflation at the mid-region. Basal and lateral lobes are almost equally developed. Polar lobe with a deep, narrow median incision. Cell wall smooth. Note: the studied specimen does not have small granules on the polar lobe angles, which are characteristic of a type variety. This fact, as well as the dimensions and shape of the cell, pointed on the fact that the species can be determined as $E$. dubium var. tritum West et G.S.West, 1908. Unfortunately, the finding of the only individual of this alga does not allow us to conclude whether this morphological feature is a characteristic of a single cell or of the entire population in the water body. Loc.: Lake Cherkaskul No 5(1). Hab.: peat bogs with Sphagnum, oligo-mesotrophic lakes and rivers. Prefers $\mathrm{pH}$ 6.5-6.6. Distr.: The species was recorded in the Polar (Patova \& Demina, 2007), Subpolar (Sterlyagova, 2008), Middle (Kossinskaya, 1960) and South (YARUSHINA et al., 2004) Urals. Widespread in the most part of the East European Plain (KosinsKaya, 1960; LuKnitskaya, 2006; ANissimova, 2017), known from West Siberia (VAleyeVA, 2006). G. distr.: widespread in both Northern and Southern Hemispheres.

Euastrum germanicum (Schmidle) Willi Krieger 1937 (Fig. 2, 4) - Dim.: 55.4-60.8 × 49.1-55.1 $\mu \mathrm{m}$, polar lobe 18.6-20.5 $\mu \mathrm{m}$ wide, and isthmus 13.2-13.7 $\mu \mathrm{m}$ wide. Descr.: cell octagonal in outline with deep 
closed sinus. Semi-cells with large inflation at the midregion, furnished with circular rows of large granules. Basal and lateral lobes are equally developed. Polar lobe with slightly concaved apex. Cell wall granulated on the surface of lobes. Loc.: Lake Boevskoye No 2(3); Lake Cherkaskul No 5(2), 7(1); Lake Bolshoye Yamskoye No 9(1). Hab.: peat bogs with Sphagnum, mesotrophic lakes and rivers. Common at slightly acidic to neutral water. Distr.: this species has not been previously recorded in the Ural Mountains or in the neighbouring regions. The nearest regions, where this species was found are the northwest (KossinsKAYA, 1960) and central (Anissimova, 2017) parts of the East European Plain and West Siberia (KossinskAYA, 1960). G. distr.: widespread in Eurasia.

Euastrum cf. insulare (Wittrock) J.Roy 1877 (Fig. 2, 5) - Dim.: $27.6 \times 20.7 \mu \mathrm{m}$, polar lobe $14.1 \mu \mathrm{m}$ wide, isthmus $6.1 \mu \mathrm{m}$ wide. Descr.: cell hexagonal in outline with deep closed sinus. Semi-cells with small inflation at the mid-region. Basal and lateral lobes are equally developed. Polar lobe with a wide, but not deep vshaped concavity. The cell wall of the studied specimen is smooth. Note: the identification of this alga is based on the morphological features of the cell. A similar species, Euastrum lacustre (Messikommer) Coesel,
1984 (Coesel, 1984; Coesel \& Meesters, 2007) can be distinguished by the cell wall structure visible in an electron microscope only. Loc.: Lake Bolshoye Yamskoye No 9(1). Hab.: peat bogs with Sphagnum, oligomesotrophic lakes and fens. Common at $\mathrm{pH}$ 4.5-7.4. Distr.: recorded in the Polar (BRIŠKAITÉ et al., 2016) and Middle (Korde, 1949; KossinsKaya, 1960) Urals. Known from the central (ANissimova, 2017) and the north-west (LUKNITSKAYA, 2013; LUKNITSKAYA, 2017) parts of the East European Plain as well as from West Siberia (KossinsKayA, 1960). G. distr.: widespread in both Northern and Southern Hemispheres.

Euastrum oblongum Ralfs 1848 (Fig. 2, 6) Dim.: 179.8-180.1 × 93.4-93.8 $\mu \mathrm{m}$, polar lobe 50.6-51.6 $\mu \mathrm{m}$ wide, isthmus $26.6-26.9 \mu \mathrm{m}$ wide. Descr.: cell narrowly elliptical in an outline with deep closed sinus. Semi-cells with three inflations at the mid-region and with one inflation on each lobe. Basal and lateral lobes are equally developed, concave on the apex. Polar lobe convex with a deep, narrow median incision. Cell wall smooth. Loc.: Lake Tenyak No 3(2). Hab.: peat bogs with Sphagnum, mesotrophic lakes and fens. Prefers pH 5.3-7.4. Distr.: recorded in the Polar (VORONIKHIN, 1930; BRIŠKAITE et al., 2016), Middle (Shaknmatov, 2014) and South
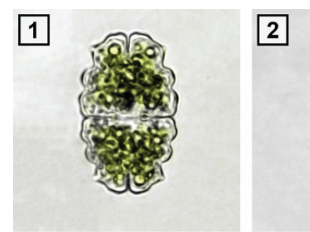

6

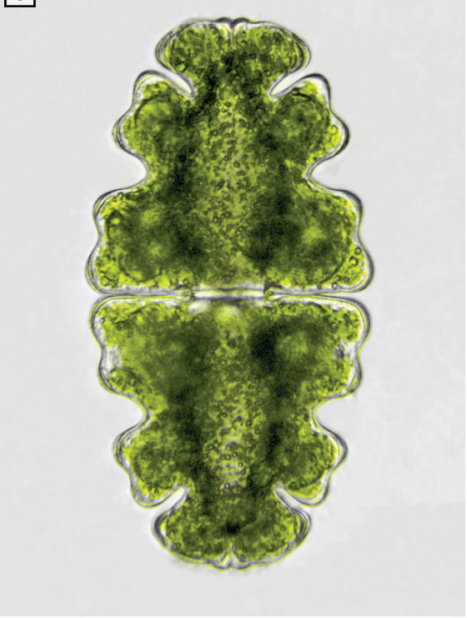

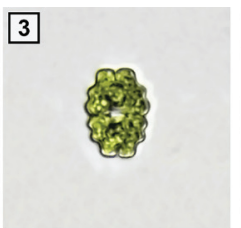

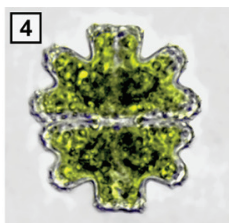

5
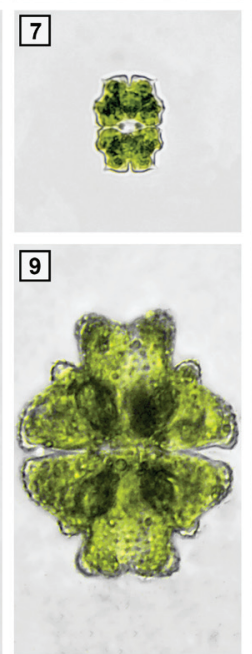

8

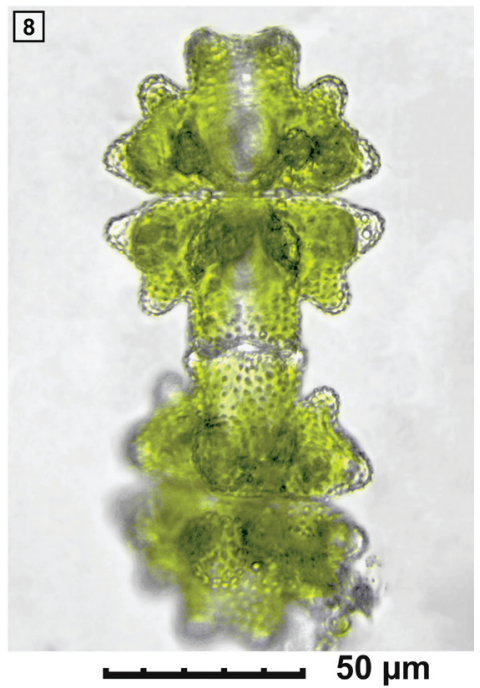

Fig. 2. Euastrum species from the studied area: $1-$ E. bidentatum, $2-$ E. cf. denticulatum, $3-$ E. dubium, $4-$ E. germanicum, $5-$ E. cf. insulare, $6-$ E. oblongum, $7-$ E. cf. pulchellum, $8-$ E. verrucosum, $9-$ E. verrucosum var. alatum 
(Snitko \& Sergeeva, 2003; Snitko, 2009) Urals. Widespread in the most part of the East European Plain (Kosinskaya, 1960; LuKNitskaya, 2006; ANisSIMOVA, 2017), and known from West Siberia (KosinSkaya, 1960; Safonova \& Shaulo, 2007; ShakhmaTOV \& PAVlovskiY, 2019). G. distr.: widespread in both Northern and Southern Hemispheres.

Euastrum cf. pulchellum Brébisson 1856 (Fig. 2, 7) - Dim.: 32.1-35.1 × 23.5-25.0 $\mu \mathrm{m}$, polar lobe $13.9-18.7 \mu \mathrm{m}$ wide, isthmus $6.7-9.7 \mu \mathrm{m}$ wide. Descr.: cell octagonal in outline with deep closed sinus. Semi-cells with a median inflation furnished with three large granules. Basal and lateral lobes are well developed, with granules at the margins. The polar lobe has a deep median incision and two spines on the angles. Loc.: Lake Boevskoye No 1(2); Lake Bolshoye Yamskoye No 9 (1). Hab.: peat bogs with Sphagnum, mesotrophic lakes and fens. Common at pH 6.7-7.4. Distr.: known from the Polar (BRIŠKAITĖ et al., 2016) and Middle (Shaкhmatov, 2014) Urals. Widespread in the most part of the East European Plain (Kosinskaya, 1960; LuKNitskaya, 2006; ANISSIMOVA, 2017), and known from West Siberia (SHAKhmatov \& Pavlovskiy, 2019). G. distr.: widespread in both Northern and Southern Hemispheres.

Euastrum verrucosum Ehrenberg ex Ralfs 1848 (Fig. 2, 8) - Dim.: 101.4-107.2 × 90.3-91.2 $\mu \mathrm{m}$, polar lobe 37.9-41.7 $\mu \mathrm{m}$ wide, isthmus $23.2-25.7 \mu \mathrm{m}$ wide. Descr.: cell octagonal in outline with deep, closed to about two thirds of its length sinus. Semicells with three inflations: one large is at the centre of a semi-cell and a single inflation is situated on each basal lobe. All inflations are furnished with circular rows of large granules. The basal lobes are larger than the lateral. Polar lobe concave. Cell wall is covered by regularly distributed granules. Note: The variety of this species, Euastrum verrucosum var. reductum Nordstedt, 1880 is known from the South Urals (SNitKo, 2009). Loc.: Lake Boevskoye No 1(3), 2(3); Lake Tenyak No 3(2); Lake Cherkaskul No 6(1). Hab.: peat bogs with Sphagnum and mesotrophic fens. Common at pH 4.5-7.8. Distr.: recorded in the Polar (BRIŠKAITĖ et al., 2016) and Subpolar (VORONIKHIN, 1930; Sterlyagova, 2008) Urals. Widespread in the most part of the East European Plain (KosinSKAYA, 1960; LUKNITSKAYA, 2006), known from West Siberia (Kosinskaya, 1960). G. distr.: widespread in both Northern and Southern Hemispheres.
Euastrum verrucosum var. alatum Wolle 1884 (Fig. 2, 9) - Dim.: 81.1-86.3 × 71.7-72.8 $\mu \mathrm{m}$, polar lobe 33.4-39.0 $\mu \mathrm{m}$ wide, isthmus $19.5-20.6 \mu \mathrm{m}$ wide. Descr.: this variety differs from the type variety by the basal lobes that have beak-shaped endings curved to the sinus. Loc.: Lake Cherkaskul No 8(2). Hab.: peat bogs with Sphagnum and mesotrophic fens. Common at $\mathrm{pH}$ 4.5-7.8. Distr.: widespread in the most part of the East European Plain (KosinSKAYA, 1960), and known from West Siberia (KosinSKAYA, 1960). G. distr.: widespread in both Northern and Southern Hemispheres.

\section{Genus Micrasterias C. Agardh ex Ralfs 1848}

Micrasterias americana Ehrenberg ex Ralfs 1848 (Fig. 3, 1) - Dim.: 128.3-130.3 × 122.9-123.5 $\mu \mathrm{m}$, polar lobe 70.4-70.8 $\mu \mathrm{m}$ wide, isthmus 30.0-31.6 $\mu \mathrm{m}$ wide. Descr.: cells hexagonal in outline with deep, closed in the most part sinus. Semi-cells with well-developed lateral lobes divided on secondary lobules of a different size. Polar lobes concave, with asymmetrically placed short additional process on each side. Cell wall is smooth, with dentation on the margins of lobes. Loc.: Lake Boevskoye No 1(1); Lake Cherkaskul No 8(1). Hab.: peat bogs with Sphagnum, mesotrophic lakes and fens. Common at pH 5-7.5. Distr.: recorded in the Subpolar (Sterlyagova, 2008) and South (SNitKo \& SNitKo, 2017) Urals. Widespread in the most part of the East European Plain (KosinSKAYA, 1960; Anissimova, 2017) and known from West Siberia (NAUMENKo, 2019). G. distr.: widespread in both Northern and Southern Hemispheres.

Micrasterias apiculata Meneghini ex Ralfs 1848 (Fig. 3, 2-3) - Dim.: 222.1-259.4 × 178.6-204.4 $\mu \mathrm{m}$, polar lobe $64.8-80.1 \mu \mathrm{m}$ wide, isthmus $34.8-40.1 \mu \mathrm{m}$ wide. Descr.: cells elliptical in outline with narrowly open sinus. Semi-cells with well-developed lateral lobes divided to the third order and median inflation with a circle of four spines. The polar lobe has v-shaped concavity and thick curved spines on the angles. Cell wall covered by the irregularly placed spines (Fig. 3, 3). Note: The samples of Micrasterias radiosa var. murrayi from Lake Medvezhye located in the South Urals (SNitKo \& SNITKo, 2017) may belong to M. apiculata. The cell size and the shape of the polar and lateral lobes as well as the characteristic location of the spines on their margins, agree with M. apiculata, which is clearly visible in the micrograph given in the paper. Unfor- 

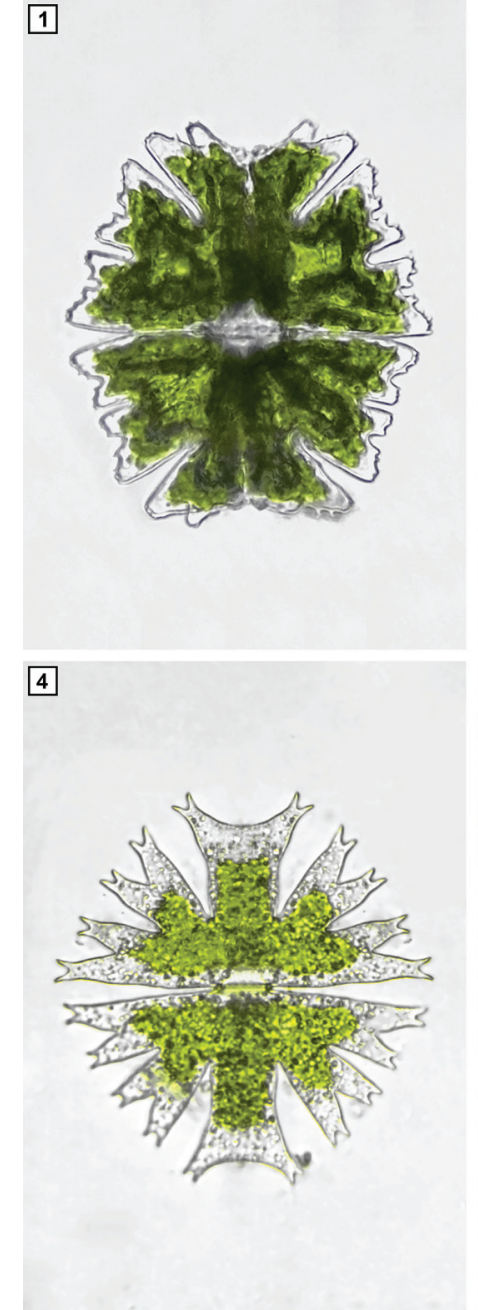
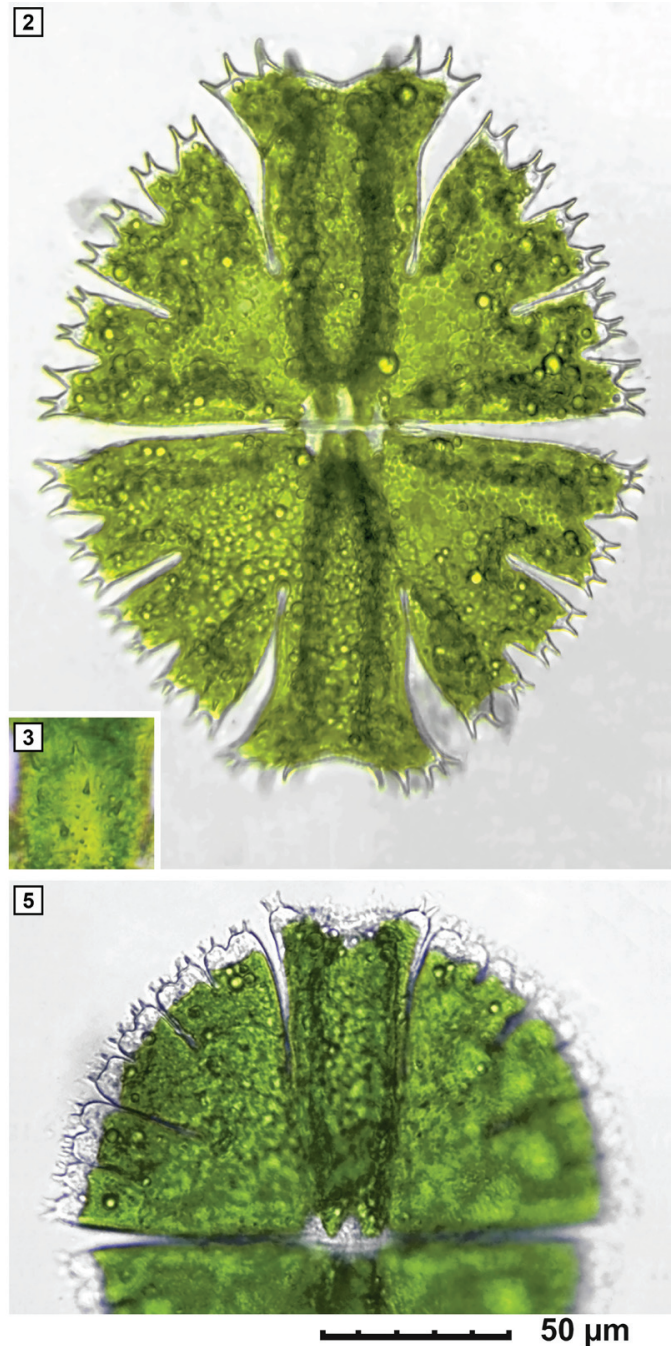

Fig. 3. Micrasterias species from the studied area: $1-$ M. americana, 2-3-M. apiculata (microphotograph 3 shows spines on the surface of the cell wall), $4-M$. crux-melitensis, $5-M$. fimbriata

tunately, the authors gave no data on the presence or absence of spines on the surface of the cell wall. Nevertheless, the distribution of $M$. apiculata may include the South Urals. Loc.: Lake Boevskoye No 1(3), 2(3); Lake Tenyak No 3(2). Hab.: peat bogs with Sphagnum, mesotrophic lakes and fens. Common at pH 5.8-6.8. Distr.: recorded in the Polar (VoronikHIN, 1930) and Middle (Shaкнмatov, 2014) Urals. Widespread in the most part of the East European Plain (Kosinskaya, 1960; Anissimova, 2017) and known from West Siberia (NAUMENKO, 2019). G. distr.: widespread in both Northern and Southern Hemispheres.

Micrasterias crux-melitensis (Ehrenberg) Trevisan 1842 (Fig. 3, 4) - Dim.: 114.1-130.3 × 104.8-127.3 $\mu \mathrm{m}$, polar lobe $36.9-40.9 \mu \mathrm{m}$ wide, isthmus $18.6-19.5$ $\mu \mathrm{m}$ wide. Descr.: cell hexagonal in outline with narrowly open sinus. Semi-cells with well-developed lateral lobes dividing to the second order. Polar lobe concave. Cell wall smooth. Note: Micrasterias cruxmelitensis is a very polymorphic species with a high number of infra-specific taxa, some of which have disputable status (Neustupa et al., 2010) and probably have no taxonomical significance. For this reason, here we present only the species name for this alga. It should be noted that all the samples found in the studied lakes can be identified as $M$. crux-melitensis var. protuberans Grönblad, which differs from the type variety by a more extended polar lobe and horizontally elongated lower lateral lobules of the second order. Loc.: Lake Boevskoye No 2(2); Lake Tenyak No 
3(2); Lake Cherkaskul No 6(1). Hab.: peat bogs with Sphagnum, mesotrophic lakes and fens. Common at pH 5.3-8. Distr.: recorded in the Polar (VoronikHIN, 1930; BrišKaité et al., 2016), Middle (ShaKhMatov, 2014; Sнакнmatov et al., 2018) and South (SNitko \& SNITKO, 2017) Urals. Widespread in the most part of the East European Plain (Kosinskaya, 1960; AnISSIMOVA, 2017), and known from West Siberia (KosinSKAYA, 1960; NAUMENKO 2019). G. distr.: widespread in both Northern and Southern Hemispheres.

Micrasterias fimbriata Ralfs 1848 (Fig. 3, 5) Dim.: $216.3 \times 194.3 \mu \mathrm{m}$, polar lobe $53.5 \mu \mathrm{m}$ wide, isthmus $35.4 \mu \mathrm{m}$ wide. Descr.: the cell is almost circular in outline, with deep, closed on the most part sinus. Semi-cells with well-developed lateral lobes, the lower of them are divided up to the third order, whereas the upper lobe is divided to the fourth order. Polar lobe concave, with two small subapical spines and two thick, slightly curved spines on its angles. Cell wall smooth. Loc.: Lake Boevskoye No 1(1). Hab.: peat bogs with Sphagnum, mesotrophic lakes and fens. Common at pH 6-7. Distr.: this species has not been previously recorded in the Ural Mountains, but widespread in the most part of the East European Plain (Kosinskaya, 1960; LuKNitskaya, 2006; AnisSIMOVA, 2017) and known from West Siberia (NAUMENKo \& PTUKhina 2013; NAUMENKo 2019). G. distr.: widespread in Eurasia and North America.

Micrasterias furcata C.Agardh ex Ralfs 1848 (Fig. 4, 1) - Dim.: 143.5-166 × 124.5-151.3 $\mu \mathrm{m}$, polar lobe 67.9-69.7 $\mu \mathrm{m}$ wide, isthmus 23.3-23.6 $\mu \mathrm{m}$ wide. Descr.: the cells are elliptical in outline with narrowly opened deep sinus. Semi-cells with welldeveloped lateral lobes divided to the third order. Lobules of the third order are strongly elongated. The polar lobe is concave, with elongated angles. Cell wall is smooth.

Note: A variety of this species, M. furcata var. pseudocrux (Grönblad) C. E. M. Bicudo \& L. Sormus (as $M$. radiata var. pseudocrux Grönblad), is known from Lake Bolshoye Miassovo in the South Urals (SNitko \& Sergeeva, 2003). Loc.: Lake Boevskoye No 1(3), 2(3); Lake Tenyak No 3(2). Hab.: peat bogs with Sphagnum, mesotrophic lakes and fens. Common at pH 6.5-6.9. Distr.: recorded in the Polar (BRIŠKaITĖ et al., 2016) and South (SNITKo \& SNITKO, 2017) Urals. Widespread in the most part of the East European Plain (Kosinskaya, 1960; ANIS-
SIMOVA, 2017), known from West Siberia (KosinSKAYA, 1960; NAUMENKo 2019). G. distr.: widespread in both Northern and Southern Hemispheres.

Micrasterias mahabuleshwarensis var. wallichii (Grunow) West et G.S.West 1905 (Fig. 4, 2) - Dim.: 183.6-186.6 × 149.0-161.1 $\mu \mathrm{m}$, polar lobe 90.8101.2 $\mu \mathrm{m}$ wide, isthmus 29.6-32.7 $\mu \mathrm{m}$ wide. Descr.: cells hexagonal in outline with widely opened sinus. Semi-cells with well-developed lateral lobes, the lowest of which is undivided, whereas the upper is divided to the second order. Polar lobe with short processes on its angles and asymmetrically placed additional processes on each side. The cell wall is covered by rows of small thick spines. Note: Earlier (Shaкнmatov, 2015) this variety was erroneously reported for this territory as M. mahabuleshwarensis var. europaea, based on the presence of small spines on the apex of the polar lobe. However, considering the size and the shape of the cell as well as the shape of the lateral lobes, we conclude that the specimens from Middle Urals belong to M. mahabuleshwarensis var. wallichii. Loc.: Lake Boevskoye No 2(2); Lake Tenyak No 4(1). Hab.: peat bogs with Sphagnum, mesotrophic moorland pools. Common in slightly acidic water. Distr.: this variety has not been previously recorded in the Ural Mountains or neighbouring regions. The nearest localities, where it was found, are the northwest part of the East European Plain (Kosinskaya, 1960; LuKNitskaya, 2010) and the Far East (Medvedeva \& Nikulina, 2014). However, the type variety of this species as well as M. mahabuleshwarensis var. europaea (W.B. Turner) Willi Krieger is known from Western Siberia (NAUMENKo, 2019). G. distr.: widespread in Eurasia, North America and Australia.

Micrasterias rotata Ralfs 1848 (Fig. 4, 3-4) Dim.: 303.4-318.6 × 257.2-275.7 $\mu \mathrm{m}$, polar lobe 50.3-61.6 $\mu \mathrm{m}$ wide, isthmus 39.3-42.3 $\mu \mathrm{m}$ wide. Descr.: cells from broadly elliptical to circular in outline with deep closed sinus. Semi-cells with well-developed lateral lobes divided to the fourth order. Polar lobe with a v-shaped concavity. Cell wall is smooth. Loc.: Lake Boevskoye No 1(3), 2(3); Lake Travyanoye No 10(1). Hab.: peat bogs with Sphagnum, mesotrophic lakes and fens with Utricularia. Common at pH 4.9-8. Distr.: recorded in the Polar (Patova \& Demina, 2007), Middle (Shakhmatov, 2014) Urals. Widespread in the most part of the East European 


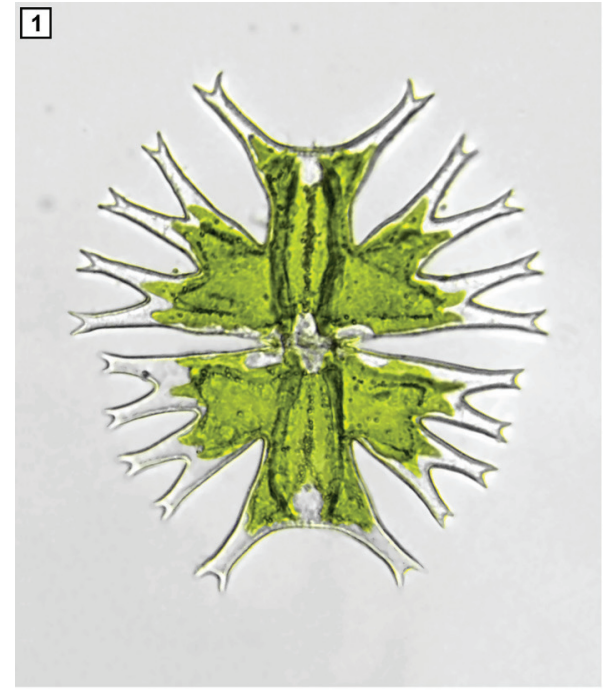

3

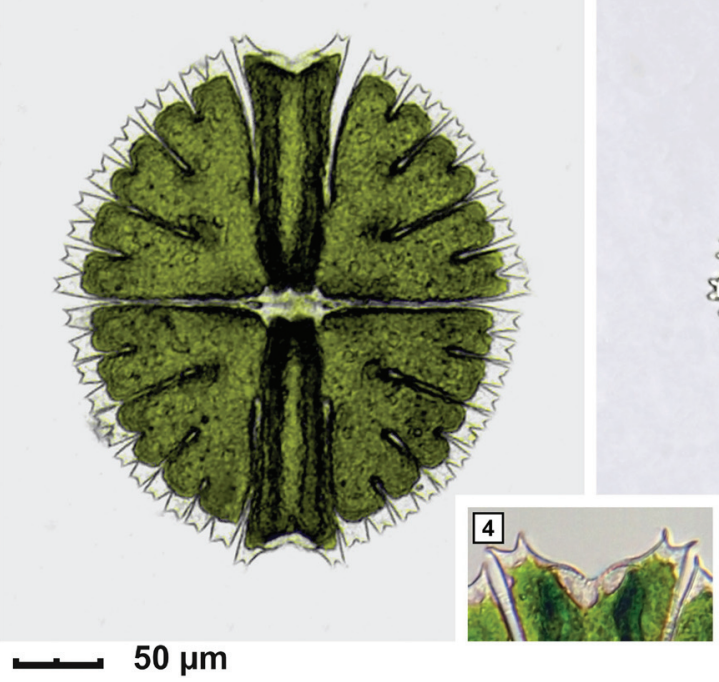

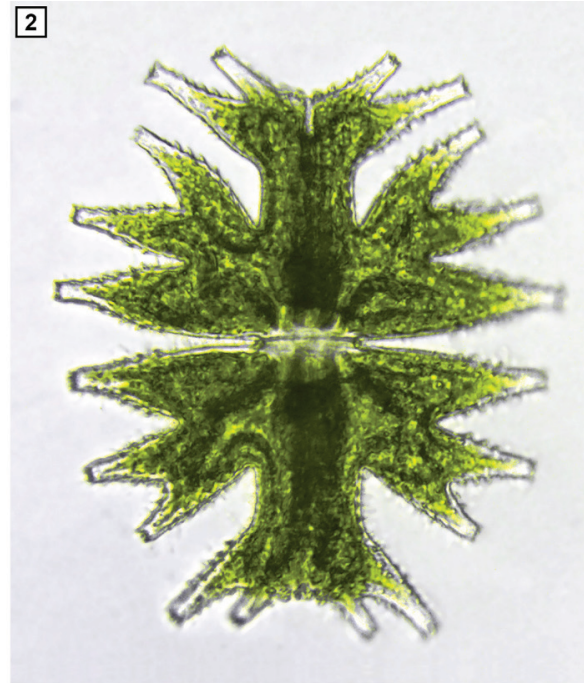

5

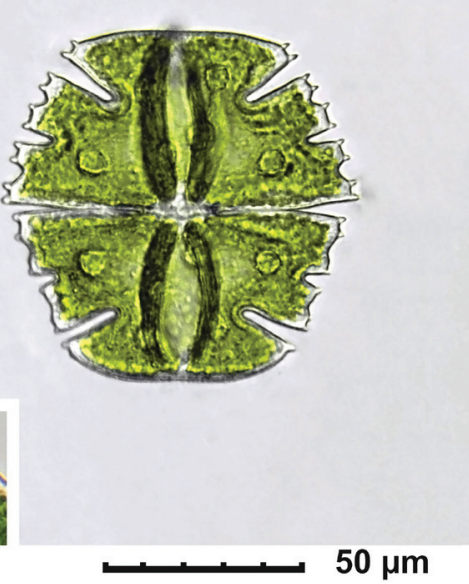

Fig. 4. Micrasterias species found in the studied area: 1 - M. furcata, 2-M. mahabuleshwarensis var. wallichii, 3-4 - M. rotata, $4-M$. rotata (a part of a polar lobe), 5-M. truncata. For the microphotograph 3, the scale is on the left; for microphotographs 1, 2, 4 and 5, the scale is on the right

Plain (KosinSKAYA, 1960; LUKNITSKAYA, 2006; ANISSIMOVA, 2017), known from the Middle Cis-Urals (Martynenko \& Boronnikova, 2016; Martynenko, 2017) and West Siberia (Kosinskaya, 1960; NAUMEnKo \& Gidora, 2017; NaumenKo 2019; Shakhmatov \& Pavlovskiy, 2019). G. distr.: widespread in both Northern and Southern Hemispheres.

Micrasterias truncata Brébisson ex Ralfs, 1848 (Fig. 4, 5) - Dim.: 96.8-111.7 × 94.9-112.5 $\mu \mathrm{m}$, polar lobe $65.1-73.9 \mu \mathrm{m}$ wide, isthmus $24.7-26.8 \mu \mathrm{m}$ wide. Descr.: cells from elliptical to almost circular in outline with deep, closed in the most part sinus. Semi-cells with well-developed lateral lobes divided to the second order. Polar lobe is slightly concave, with 1-2 short thick spines on the angles. Cell wall is smooth. Loc.: Lake Boevskoye No 1(2); Lake Travyanoye No 10(1). Hab.: peat bogs with Sphagnum, mesotrophic lakes and fens. Common at $\mathrm{pH}$ 4.5-7. Distr.: recorded in the Subpolar (VORONIKHIN, 1930) and South (SNitKo \& SNitKo, 2017) Urals. Widespread in the most part of the East European Plain (KosinsKaya, 1960; LuKNITSKAYA, 2006; ANIssimova, 2017), known from the Middle Cis-Urals (Martynenko, 2017) and West Siberia (Kosinskaya, 1960; Naumenko, 2019). G. distr.: widespread in both Northern and Southern Hemispheres. 


\section{RESULTS AND DISCUSSION}

The worldwide diversity of the genera Euastrum and Micrasterias is about $189-265$ and 56-75 species, respectively (Gontcharov, 2008; GUIRY, 2013). Despite the large number of species, these groups are poorly represented in the Ural Mountains. To date, only 27 Euastrum and 16 Micrasterias species have been recorded in the Urals. The highest number of the Euastrum and Micrasterias, namely 15 and 8 species and sub-specific taxa, respectively, have been found in water bodies and wetlands of the Polar Urals (BRIŠKAITE et al., 2016; Patova \& Demina, 2007, 2008; VoronIKHIN, 1930). Smaller number of species are known from the Subpolar (14 Euastrum and 4 Micrasterias) and Southern (6 Euastrum and 10 Micrasterias) Urals (Snitko \& Sergeeva, 2003; Snitko, 2009; Snitko \& SNitKo, 2017; Sterlyagova, 2008; Voronikhin, 1930; Yarushina et al., 2004). Middle Urals has up to date the lowest diversity -8 Euastrum and 4 Micrasterias species (Bogdanov et al. 2007; Korde, 1949; ShaKHMAtov, 2014; Shakhmatov, 2017).

In the current study, nine taxa (eight species and one variety) that belong to the genus Euastrum and eight taxa from the genus Micrasterias were found in the studied lakes. Four species (Euastrum germanicum, E. verrucosum var. alatum, Micrasterias fimbriata, M. mahabuleshwarensis var. wallichii) were discovered within the Ural Mountains Region for the first time. These species along with Euastrum verrucosum, Micrasterias americana, $M$. furcata $M$. truncata have not been previously found in Middle Urals.

The species of the Euastrum and Micrasterias were found only in five lakes - Boevskoye, Tenyak, Cherkaskul, Bolshoye Yamskoye and Travyanoye, where the fen habitats are most developed. However, these reservoirs were not equally rich in the species composition of the studied genera. The highest similarity level (42.8\%) of the Euastrum and Micrasterias species composition was observed in Lakes Boevskoye and Tenyak. These lakes were the most species rich: in the first one, five species of the Euastrum and all eight species of the Micrasterias were found, while from the second lake, three species of the Euastrum and four species of the Micrasterias were reported. It is noteworthy that almost all taxa found in these two lakes perform a fairly high abundance, with the exception of three species - Euastrum bidentatum,
Micrasterias crux-melitensis and M. fimbriata. Lake Cherkaskul has a significantly lower level of similarity $(18.8 \%)$ with the afore-mentioned water reservoirs; three species of the Euastrum and four species of the Micrasterias were found in it. Only Euastrum germanicum had its highest abundance in this lake. The lowest similarity with other studied water reservoirs was observed in Lakes Bolshoye Yamskoye and Travyanoye, where only two Euastrum and two Micrasterias species were found, respectively.

The assessment of the influence of such important for desmid algae physicochemical parameters as water temperature and $\mathrm{pH}($ ВRоOK, 1981) showed that the effect of temperature was not significant, but $\mathrm{pH}$ significantly $(\mathrm{CCA}, p=0.01$, pseudo-F $=1.7)$ explained $30 \%$ of the data variability. The most abundant species prefer neutral to slightly acidic water, which is consistent with literature data on their ecology (KosinsKaYA, 1960; Coesel \& MeEsters, 2007; ŠŤastný, 2010; AnISSimova, 2017; Naumenko, 2019) (Fig. 5). Preference of slightly acidic and neutral values of $\mathrm{pH}$ by the studied taxa partly clarifies their absence in other studied lakes, where $\mathrm{pH}$ values ranged from 8 to 9 .

In parallel with the assessment of the influence of physicochemical factors, the analysis of habitat preferences of the detected algae was carried out. Based on the results presented in Fig. 5, some of the species were attributed to the inhabitants of plankton (Euastrum germanicum, E. oblongum and Micrasterias cruxmelitensis), some were associated both with plankton

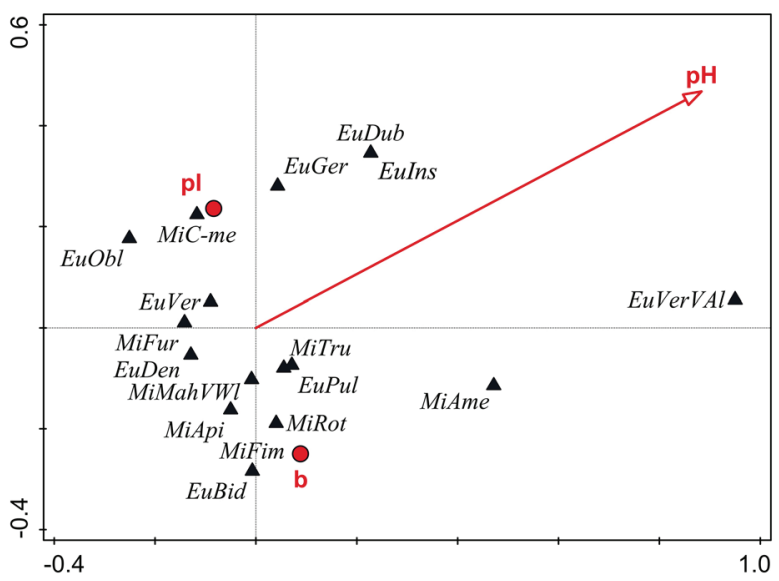

Fig. 5. CCA biplot describing the abundance of the Euastrum and Micrasterias species in relation to $\mathrm{pH}$ and habitats ( $\mathrm{pl}-$ planktonic, $\mathrm{b}$ - benthic). Abbreviations of species include the first two letters of a genus, three letters of species names, and two letters of a variety name 
and benthos (Euastrum cf. denticulatum, E. verrucosum and Micrasterias furcata), whereas most of the species were found predominantly in benthic habitats.

Comparison of the investigated flora with literature data on different parts of the Ural Mountains (Fig. 6) showed a low similarity level ranging from $21 \%$ with the species composition of the genera in the Polar Urals to $38 \%$ with the floras of the Middle and Polar Urals. Moreover, the similarity of the species composition between different parts of Ural Region was also low (from 11 to 35\%). Nevertheless, such level of similarity may be explained rather by a poor knowledge of algal floras than by its peculiarities, especially considering the fact that most of the algae found in the Ural Mountains are widely distributed around the world from equatorial to Polar Regions.

Summing up, the Euastrum and Micrasterias flora of the studied reservoirs consists mostly of acidophilic and benthic species, which is characteristic of the algae under consideration. However, the significant number of species recorded for the first time in the territory of the Ural Mountains and particularly in Middle Urals points to the fact that algal flora of the region is still quite poorly investigated.

\section{ACKNOWLEDGEMENTS}

We express our gratitude to A.G. Paukov (Ural Federal University, Ekaterinburg, Russia) for reading the manuscript and for useful comments. We also thank A.F. Luknitskaya (V.L. Komarov Botanical
Institute RAS, St Petersburg, Russia) for invaluable help with determination of some species. We appreciate comments of anonymous reviewers, who have greatly improved the manuscript.

\section{REFERENCES}

Aleksyuk V.A., Semenova L.A., Skrypkina S.V., 1989: Al'goflora sorovoj sistemy Ob'-Irty skogo bassejna. - In: YARUSHINA M.I. (ed.), Gidrobiologičeskaja xarakteristika vodoëmov Urala: Sbornik naučnyx trudov: 3-12. - Sverdlovsk.

Andreeva M.A., 1973: Ozëra Srednego i Južnogo Urala. - Čeljabinsk.

Anissimova O.V., 2017: Desmids of sphagnum bogs of the Moscow region: species diversity and ecological preferences. - Transactions of IBIW RAS, 79(82): 10-18.

Barinova S.S., Medvedeva L.A., 1996: Atlas vodoroslej - indikatorov saprobnosti (rossijskij Dal'nij Vostok). - Vladivostok.

Bogdanov V.D., Bogdanova Ye.N., Goskova O.A., Morozova L.M., Nekrasova L.S., Stepanov L.N., YARUSHINA M.I., 2007: Ocenka ekologičeskogo sostojanija i rekreacionnoj emkosti ekosistemy ozera Pesčanoe. - Ekaterinburg.

BrišKaitė R., Patova E., Juzėnas S., 2016: Desmid flora in the lakes of the Khrebtovyi Nature Reserve in the Polar Ural (Russia). - Botanica Lithuanica, 22(2): 113-122.

BRоок A.J., 1981: The biology of desmids. - Oxford.
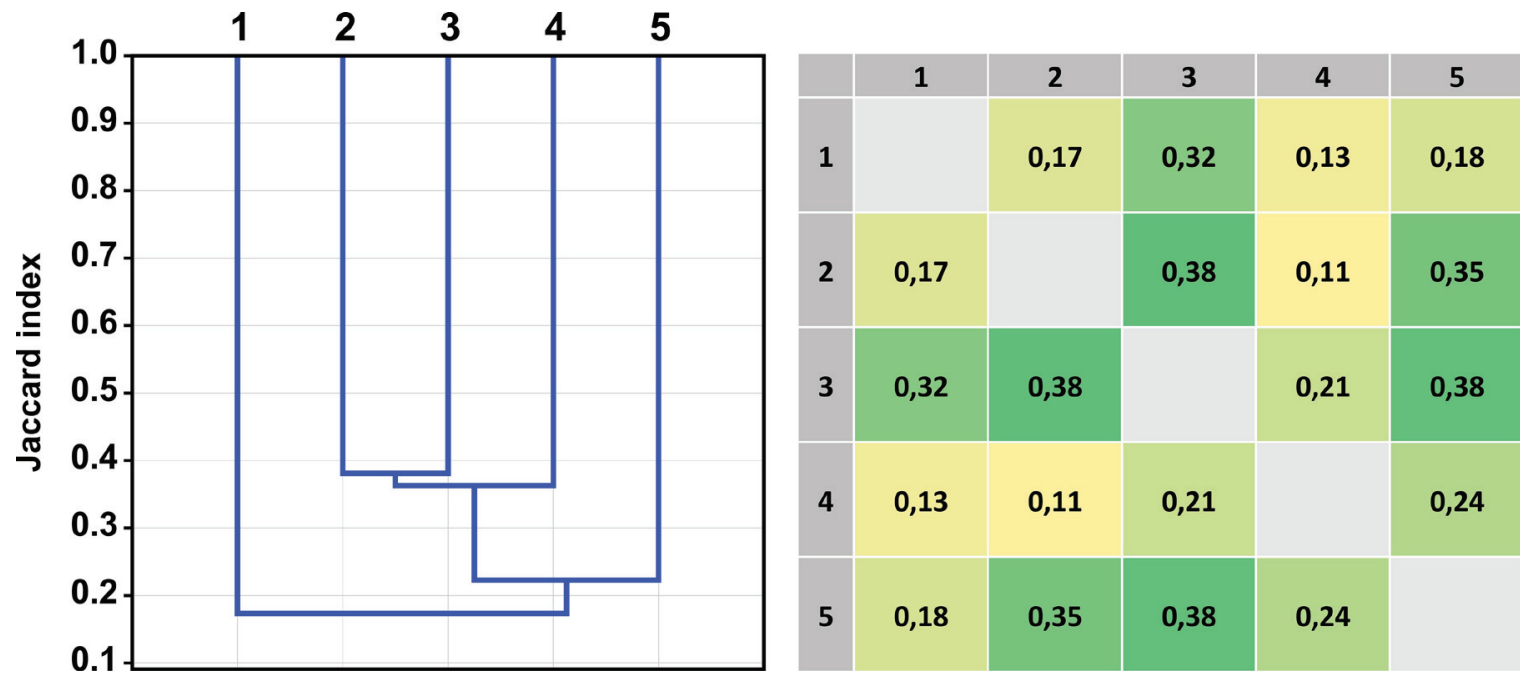

Fig. 6. Dendrogram and matrix (the Jaccard index) showing similarity of the identified Euastrum and Micrasterias flora (3) with literature data on the South (1), Middle (2), Subpolar (4) and Polar (5) Urals 
Chibilyov A.A., Chibilyov A.A., 2012: Natural zonation of the Urals based on latitudinal belts, elevation zones and vertical differentiation of landscapes. - Izvestija Samarskogo Naučnogo Centra Rossijskoj Akademii Nauk, 1(6): 1660-1665.

Coesel P.F.M., 1975: The relevance of desmids in the biological typology and evaluation of fresh waters. - Hydrobiological Bulletin, 9: 93-101.

Coesel P.F.M., 1984: Taxonomic implications of SEM revealed cell wall sculpturing in some small-sized desmid species (Chlorophyta, Conjugatophyceae). - Acta Botanica Neerlandica, 33: 385-398.

Coesel P.F.M., Meesters K.J., 2007: Desmids of the lowlands. - Zeist.

ERemkina T.V., 2009: Phytoplankton Composition and Structure of Itkul, Sinara and Silach Lakes. Bulletin of Chelyabinsk State University, 10: 267-277.

Gontcharov A.A., 2008: Phylogeny and classification of Zygnematophyceae (Streptophyta): current state of affairs. - Fottea, 8: 87-104.

GuiRy M.D., 2013: Taxonomy and nomenclature of the Conjugatophyceae (= Zygnematophyceae). Algae, 28(1): 1-29.

Guiry M.D., Guiry G.M., 1996-2019: AlgaeBase. http://www.algaebase.org [Accessed: 8 October 2019].

HAMmer Ø., Harper D.A.T., Ryan P.D., 2001: PAST: Paleontological statistics software package for education and data analysis. - Palaeontologia Electronica, 4(1): 1-9.

KordE N.V., 1949: Istorija algoflory nekotoryx ozer Srednego Urala. - In: Sukachov V.N. (ed.), Trudy laboratorii sapropelevyx otloženij. Vypusk 3: 68100 - Moskva.

Korde N.V., 1956: Metodika biologičeskogo izučenija donnyx otloženij ozer. - Žizn' presnyx vod SSSR, 4(1): 108-127.

KosInSKAYA E.K., 1960: Flora sporovyx rastenij SSSR. Konjugaty. Desmidievye Vodorosli 5(2). Moskva-Leningrad.

Kulikov P.V., 2010: Opredelitel sosudistyx rastenij Čeljabinskoj oblasti. - Ekaterinburg.

LENZENWEGER R., 1996: Desmidiaceenflora von Österreich, 1. - Berlin-Stuttgart.

LUKNITSKAYA A.F., 2006: Synopsis of conjugate flora (Streptophyta, Zygnematophyceae) of the north
Russia. - Novosti Sistematiki Niz ix Rastenij, 40: 49-82.

Luknitskaya A.F., 2010: To the algal flora (Streptophyta, Zygnematophyceae) of some bogs and swamp areas of the Karelian Isthmus (Leningrad Region, Russia). - Novosti Sistematiki Niz ix Rastenij, 44: 81-89.

LuKNitskayA A.F., 2013: To the flora of Zygnematophyceae (Streptophyta) of Valdajskoe Lake (Novgorod Region, Russia). - Novosti Sistematiki Niz ix Rastenij, 47: 62-67.

Luknitskaya A.F., 2017: Conjugates (Charophyta, Conjugatophyceae) of the National Park "Valdajskij" (Novgorod Region, Russia). - Novosti Sistematiki Niz ix Rastenij, 51: 106-120.

Martynenko N.A., 2017: Culture collection of desmids from the mires of the Perm territory (Russia). - Transactions of IBIW RAS, 79(82): 110114.

MartynenKo N.A., BoronniKova S.V., 2016: Algae of order Desmidiales from ponds of Perm Krai.-Modern Problems of Science and Education, 3. https:// www.science-education.ru/pdf/2016/3/24792.pdf [Accessed: 25 March 2020].

Medvedeva L.A., Nikulina T.V., 2014: Catalogue of freshwater algae of the southern part of the Russian Far East. - Vladivostok.

NaumenKo Y.V., 1992: Species composition of desmids (Desmidiales, Chlorophyta) of the Ob River. - Botaničeskij Žurnal, 77(11): 89-93.

NAumenko Y.V., 2019: Ecological characteristics of species of the genus Micrasterias C.Agardh ex Ralfs (Family Desmidiaceae) in West Siberia (Russia). - Sibirskij Ekologičeskij Žurnal, 2: 232-237.

Naumenko Y.V., Gidora O.Y., 2017: Micrasterias C. Agarth ex Ralfs species in the Natural Park "Sibirskie Uvaly" (West Siberia, Russia). Ukrainian Journal of Ecology, 7(2): 116-119.

Naumenko Y.V., Ptukhina O.Y., 2013: Desmids algae (Desmidiales) of the Natural Park "Sibirskie Uvaly", West Siberia, Russia. - Turczaninowia, 16(2): 81-83.

Neustupa J., Skaloud P., St’astny J., 2010: The molecular phylogenetic and geometric morphometric evaluation of Micrasterias crux-melitensis/ $M$. radians species complex. - Journal of Phycology, 46(4): 703-714. 
Patova E.N., Demina I.V., 2007: Algae of other divisions. - In: Getsen M.V. (ed.), Biodiversity of the Polar Ural ecosystems: 69-89. - Syktyvkar.

Patova E.N., Demina I.V., 2008: Algae in Anthropogenically Unaffected Water Bodies of the Polar Urals. - Inland Water Biology, 1: 54-63.

SAFOnOva T.A., Shaulo S.P., 2007: The addition to algoflora of the water bodies of the middle taiga of the West Siberia. - Turczaninowia, 10(2): 50-71.

Shaknmatov A.S., 2014: The first information on species composition of the conjugating green algae (Conjugatophyceae) in "Chusovaya River" Natural Park. - Voprosy Sovremennoj Al'gologii, 2(6).http://algology.ru/652 [Accessed: 25 March 2020].

Shakhmatov A.S., 2015: First information on the conjugating green algae (Streptophyta, Conjugatophyceae) species composition in overgrown lakes of the southern Sverdlovsk Region. - Novosti Sistematiki Niz ix Rastenij, 49: 117-123.

Shakhmatov A.S., Pavlovskiy E.V., 2019. Diversity of desmid algae (Charophyta: Conjugatophyceae) in the vicinity of Yugorsk city (KMAO-Yugra, Russia). - Folia Cryptogamica Estonica. 56: $11-22$.

Shakhmatov A.S., Pavlovskiy E.V., Paukov A.G., 2018: Desmid algae (Charophyta: Conjugatophyceae) of Ekaterinburg, Middle Urals, Russia. - Folia Cryptogamica Estonica, 55: 7-15.

Snitko L.V., 2009: Èkologija i sukcessii fitoplanktona ozër Južnogo Urala. - Miass.

Snitko L.V., Sergeeva R.M., 2003: Vodorosli razno- tipnyx vodoëmov vostočnoj časti Južnogo Urala. - Miass.

Snitko L.V., Snitko K.V., 2017: Micrasterias C. Agardh (Conjugatophyceae) in wetlands of east foothills of the South Urals. - Voprosy Sovremennoj Algologii, 1(13). http://algology. ru/1082 [Accessed: 25 March 2020].

Sterlyagova N.I., 2008: Desmids in mountain lakes of the Subpolar Urals. - Biologia, 63(6): 911-916.

ŠŤASTNÝ J., 2010: Desmids (Conjugatophyceae, Viridiplantae) from the Czech Republic; new and rare taxa, distribution, ecology. - Fottea, 10: 1-74.

TAusson A.O., 1947: Vodnye resursy Molotovskoj oblasti. - Molotov.

ter Braak C.J.F., Šmilauer P., 2012: Canoco Reference Manual and User's Guide: Software for Ordination (Version 5.0). - Ithaca.

Valeyeva E.I., 2006: On algoflora of certain lakes in south Tyumen Lake District. - Bulletin of Ecology, Forest Science and Landscape Science, 7: $42-50$.

Voronikhin N.N., 1930: Vodorosli Poljarnogo i Severnogo Urala. - Trudy Leningradskogo Obščestva Estestvoispytatelej, 60(3): 1-71.

Yarushina M.I., ERemkina T.V., 2000: Fitoplankton ozër Sinarskoj gruppy Čeljabinskoj oblasti. - Ecology and rational nature management at the turn of the century: results and prospects, 1 : 228-230.

Yarushina M.I., Tanaeva G.V., Eremkina T.V., 2004: Flora vodoroslej vodoëmov Čeljabinskoj oblasti. - Ekaterinburg.

\section{EUASTRUM IR MICRASTERIAS (CHAROPHYTA, DESMIDIALES) GENČIŲ DVYNIEČIAI VIDURIO URALO (RUSIJA) PIETINĖS DALIES EŽERUOSE}

\section{Andrei S. Shakhmatov}

\section{Santrauka}

Floristinio dvyniečių tyrimo metu Vidurio Uralo pietinès dalies ežeruose buvo aptiktos devynios Euastrum genties ir aštuonios Micrasterias genties rūšys ir vidurūšiniai taksonai. Jų tarpe, keturi taksonai (Euastrum germanicum, E. verrucosum var. alatum, Micrasterias fimbriata, M. mahabuleshwarensis var. wallichii) buvo pirmą kartą aptikti Uralo regione, tuo tarpu kitos keturios rūšys (Euastrum verrucosum, Micrasterias americana, M. furcata and M. truncata) - naujos Vidurio Uralo regionui. Rūšių prieraišumo buveinès atžvilgiu ịvertinimui atlikta kanoninè korespondencijos analizè parodè, kad dauguma rūšių gausiau vystėsi silpnai rūgštiniuose ežeruose ir vyravo bentoso buveinèse. 